\title{
Successful Surgical Management of Congenital Defect: Atresia Ani in a one-Day Old Zebu Cow Calf
}

\author{
MD Zulfekar Ali* \\ Division of Animal Health Research, Bangladesh
}

*Corresponding author: MD Zulfekar Ali, Division of Animal Health Research, Bangladesh Livestock Research Institute (BLRI), Savar, Dhaka-1341, Bangladesh

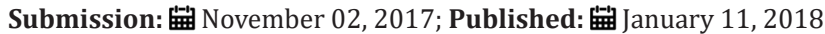

\begin{abstract}
The successful surgical management of a zebu male cow calf at the age of one-day with atresia ani due to pathological absence of anal opening was performed successfully in the Veterinary Teaching Hospital, Hajee Mohammad Danesh Science and Technology, University, Dinajpur-5200, Bangladesh. The operative technique with post operative care and management are described.

Keywords: Atresia ani; Calf; Surgery
\end{abstract}

\section{Introduction}

Surgical affections in cow calves comprise both congenital and acquired disorders. In Bangladesh, umbilical hernia, dermoid cyst, non-functional limb joints, supernumerary limbs and atresia ani have been reported to occur in the calves [1]. About $20.00 \%$ calves are recorded of atresia ani [2]. Intestinal atresia is reported as a congenital defect in all domestic animals species [3]. The anal and rectal congenital abnormalities are fairly common in young calves $[3,4]$. Various surgical techniques have been used to correct atresia ani in domestic animals [5,6]. This report demonstrated a clinical case of atresia ani in a male zebu calf, which was corrected successfully by surgical intervention.

\section{Materials and Methods}

A day old male cow calf of indigenous breed was presented at Veterinary Teaching Hospital, Hajee Mohammad Danesh Science and Technology University, Dinajpur-5200 with the complain of non-passage of faeces since birth. On clinical observation, it was found that the calf didn't have anal opening (Figure 1). There was soft subcutaneous swelling under the ischial arch with enlargement of abdomen. The signs of abdominal pain were observed. The case was diagnosed as atresia ani condition and planned for surgery.

\section{Operative Technique}

The calf was controlled in dorso-ventral position with its hindquarter raised high on a table and restrained. Below the base of the tail the perineal area was prepared for aseptic surgical location. Local infiltration anaesthesia was performed using injection $2 \%$ lignocaine hydrochloride (Jasocaine- $A ®$, Jayson Bangladesh Ltd.) solution at the proposed site of incision.
A circular piece of skin was excised over the anal site grasping by rat tooth forceps upon the bulge of the anus (Figure 1). Hard Muconium came out immediately. To drainage meconium properly, $0.001 \%$ Potassium permanganate solution was inserted through a plastic pipe according to same size of rectal lumen. After sufficient evacuation of the bowel the rectal wall is approsed to the skin by application of interrupted sutures by black braided silk 2 to make a permanent anal orifice (Figure 2) [7]. Post-operatively, the surgical wound was cleaned and dressed regularly with liquid povidone iodine, coconut oil and ointment acrilin was applied daily till recovery and injection ceftriaxone (Inj. Trizon vet $囚$, The ACME Laboratories Ltd.) $3 \mathrm{ml}$ was given intramuscular daily for 5 days. An antibiotic therapy was followed for 5 days. The sutures were removed on the $10^{\text {th }}$ post-operative day.

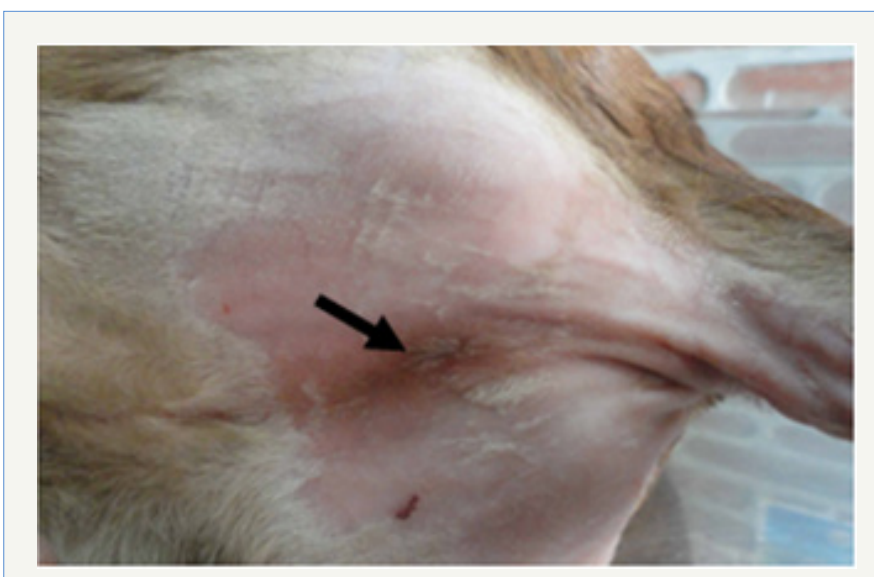

Figure 1: Absence of anal opening. 


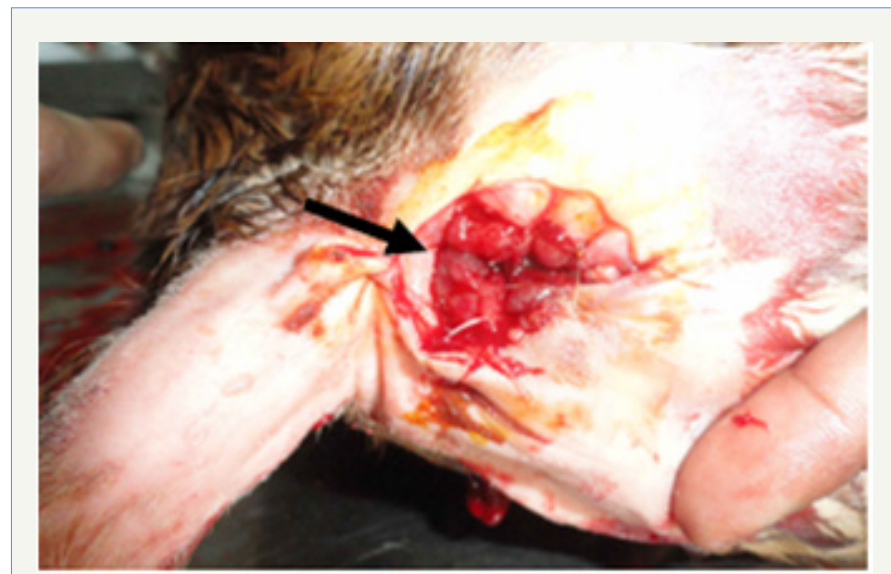

Figure 2: A permanent anal orifice was made.

\section{Results and Discussion}

The zebu calf showed noticeable improvement in defecation and general behavior within $3^{\text {rd }}$ day of post surgery and everyday recovery within $10^{\text {th }}$ post-operative day. The present case of atresia ani with its simple form of agenesis (without involving other parts) uneventful recovery after surgical intervention and similar findings in calves were reported by $[8,9]$. The majority affected calves primarily will stand and suckle normally after birth [10]. The time for start of clinical signs of this condition may be vary from 1 to 3 days. On collection of history the owner did not see the calf passing muconium or feces was the main observation. The principal clinical sign of condition was straining, tenesmus, colic, depression and anorexia with abdominal distention [11]. The diagnosis of atresia ani is often presumptive based on the age, history, and physical examinations. Diagnosis of atresia ani can be performed easily by visual inspection of the perineal region under base of tail or by gentle digital palpation if a vestigial anal opening is present. Surgical intervention is the only technique of choice for the treatment in such acute abdominal discomfort and it was attempted successfully in this present case.

\section{Acknowledgement}

Author kindly acknowledge the all technicians of Veterinary Teaching Hospital, Hajee Mohammad Danesh Science and Technology, University, Dinajpur-5200, Bangladesh for their cordial help to perform the surgery.

\section{References}

1. Anwar S, Purohit GN (2012) Rare congenital absence of tail (anury) and anus (atresia ani) in male camel (Camelus dromedarius) calf. Open Vet J 2(1): 69-71.

2. Das BR, Hashim MA (1996) Study on Surgical Affections of Calves. Bangladesh Vet J 30 (1-2): 53-57.

3. Ali MZ, Sultana S, Rahman MT, Islam MS (2013) Economics of fertility management of small holding dairy farms in Bangladesh. Iran J Applied Anim Sci 3(3): 509-512.

4. Dreyfuss DJ, Tulleners EP (1989) Intestinal atresia in calves: 22 cases (1978-1988). J Am Vet Med Assoc 195(4): 508-513.

5. Khokon MSI, Azizunnesa, MM Islam, KB Chowdhury, ML Rahman, et al. (2017) Effect of mastitis on post-partum conception of cross bred dairy cows in Chittagong district of Bangladesh. J Adv Vet Anim Res 4(2): 155160 .

6. Jubb KVF, Kennedy PC, Palmer N (1993) Pathology of domestic animals. Academic press, London.

7. Kersjes AW, Nemeth F, Rutgers LJE (1984) Atlas of large animal surgery, Williams \& Wilkins Baltimore/London. Chapter 4 THE ABDOMEN/ Gastro intestinal system, pp. 4-14.

8. Suthar DN, Chaudhary SR, Patel PB, Mistry JN, Patel JB, et al. (2010) Surgical management of atresia ani in a cow calf. Vet Pathol 17: 565-74.

9. Nagaraja BN, Usturge SM, Sonwane SD, Ramkrishna V, Manjunath MG (2001) Fused vulval lips in association with recto-vaginal fistula and atresia ani-et-recti in a calf. Indian J Vet Surg 22(2): 125-126.

10. Ali MZ, S Sultana (2013) Isolation and identification of bacteria from tracheas and lungs of buffaloes in Dinajpur. Stamford J Microbiol 2(1): 31-33.

11. Mallesh P, Sampath K, Raju G (2017) Successful management of atresia ANI (congenital defect) in non-descript calf: A case report. The Pharma Innovation 6(7): 337-338. 